\title{
Sedimentological and palynological investigations of the Neoproterozoic Valdres Group
}

\author{
Even Stokkebekk', Eirik N. Nordeng', Henning Dypvik', Rikke Ø. Småkasin', \\ Kathrine Sørhus' \& Wolfram M. Kürschner ${ }^{1}$
}

${ }^{1}$ Department of Geosciences, University of Oslo, P.O.Box 1047, NO-0316 Oslo, Norway

E-mail corresponding author (Henning Dypvik): henning.dypvik@geo.uio.no

The Valdres Group (?Cryogenian) has been sedimentologically and stratigraphically studied and sampled in a few key sites (Grønsennknippa, Mellane, Ormtjernkampen). The search for fossils in selected formations has been the target and one identified acantomorphic acritarch was discovered along with other organic matter of more uncertain heritage. In addition to the diamictite/tillite present in the Valdres Group succession, this facilitates a correlation with the well-known Hedmark Group to the east.

Keywords:Valdres Group, sedimentology, stratigraphy, palynology, acritarch

Received 17. June 2019 / Accepted 4. October 2019 / Published online 30. October 2019

\section{Introduction}

In southern Norway a possibly more than 4000 m-thick Neoproterozoic succession exists in the Hedmark and Valdres basins (Figs. 1, 2 \& 3). The Hedmark Group of the Hedmark Basin is well studied and palynomorphs have been found (Vidal \& Nystuen, 1990b) in the succession, which was formed by rifting along the western margin of the continent Baltica 750-600 million years ago (Lamminen et al., 2015).

The stratigraphy of the well-studied Hedmark Group from the Mjøsa-Gudbrandsdalen-Østerdalen region can be correlated with the less studied but possibly time-equivalent Valdres Group (formerly Valdres Sparagmite) of the Valdres Basin. The Valdres Group potentially carries some age information through lithostratigraphical correlations with the Hedmark
Group (Nystuen, 1982; Lamminen et al., 2015), but so far no fossils or radiometric datings have been reported. Consequently, the ongoing Valdres Project at the University of Oslo (UiO) aims to shed new light on the geological development of the Valdres Group (Småkasin, 2017; Sørhus, 2017; Nordeng, 2018; Stokkebekk, 2018).

The current paper presents the first discovery of organicwalled microfossils from the Valdres Group. The results are part of a series of MSc studies at $\mathrm{UiO}$ with the primary aim to investigate the sedimentology, petrography and stratigraphy of the Neoproterozoic meta-sedimentary rocks of the Valdres Group. During the course of these investigations, some of the sediment samples collected in the field were selected and processed for palynological analysis. A more detailed stratigraphical and sedimentological examination of the Valdres Group, and regional comparisons, are in progress (Dypvik et al., in prep). 


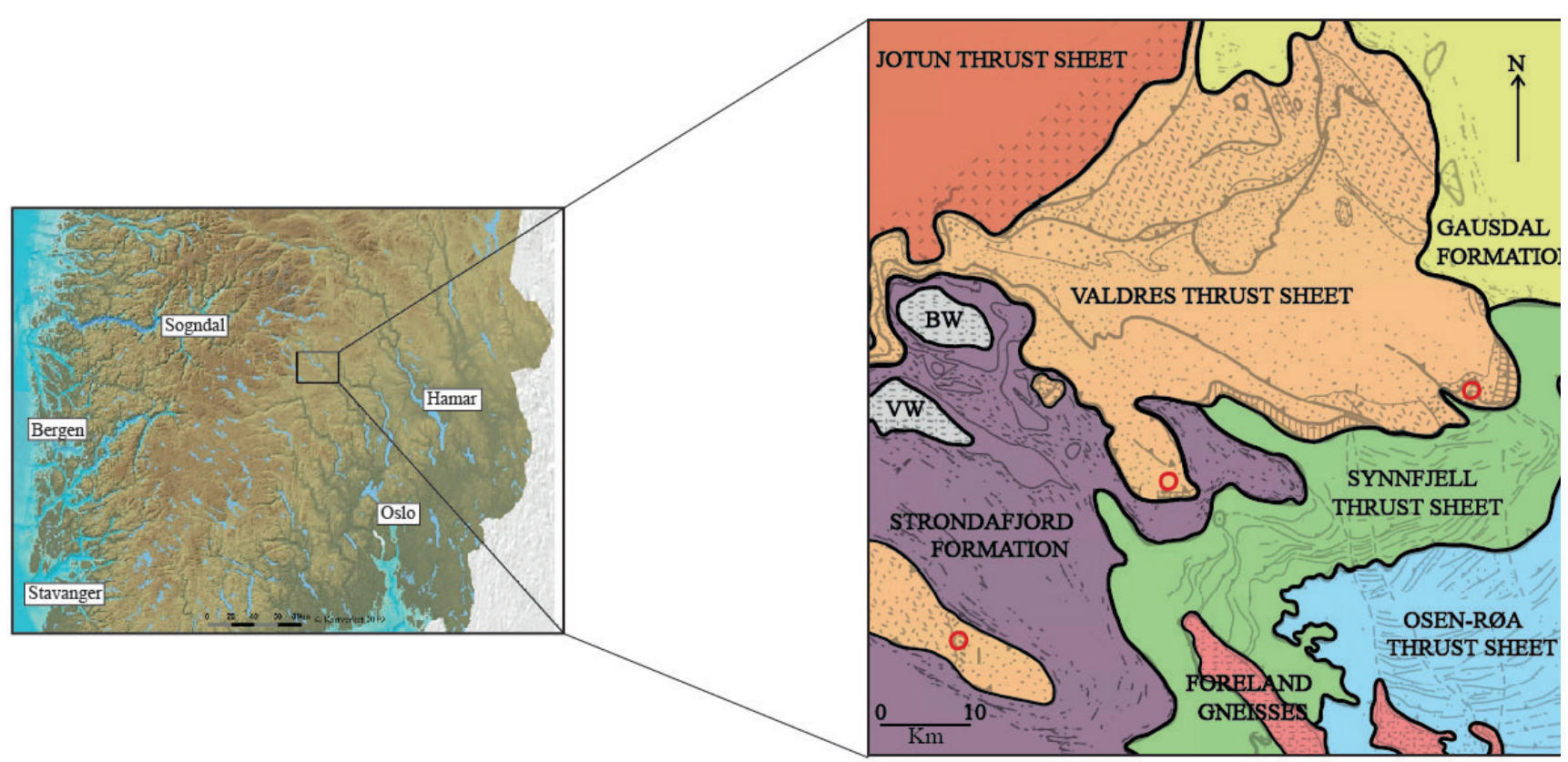

Figure 1. Simplified geological map of the Valdres and adjacent areas in southern Norway showing the thrust sheets of the Lower Allochthon (Synnfjell and Osen-Røa) and the Middle Allochthon (Jotun and Valdres thrust sheets). The Hedmark Group is located in the Osen-Røa Thrust Sheet, while the Valdres Group belongs to the Valdres Thrust Sheet. The studied Valdres sites are marked by red circles; Grønsennknippa to the SW, Mellane (Skarvemellen and Rundemellen) in the middle and Ormtjernkampen to the NE. The basement windows are shown in brown, where BW is the Beito window and VW is the Vang window (Modified from Nickelsen et al., 1985; Sørhus, 2017).

\section{Geological background of the Valdres Group}

The Neoproterozoic Valdres Group is dominated by arkosic sediments, deposited in a continental rift basin (Valdres Basin) at the Baltoscandian margin. The Valdres Group (Fig. 2) comprises successions of varying lithostratigraphy, including gabbroic and quartzitic conglomerates, arkoses, feldspathic wackes, arenites rich in gabbroic detritus and possible diamictite/ tillite (Hossack et al., 1985). An original thickness of possibly more than $4000 \mathrm{~m}$ has been suggested for the group (Hossack, 1968; Loeschke \& Nickelsen, 1968). The top of the Valdres Group is marked by a tillite horizon, which has been described from the Mellane and Ormtjernkampen sections (Loeschke \& Nickelsen, 1968). It separates the group from the overlying Cambrian-Ordovician Mellsenn Group (Loeschke \& Nickelsen, 1968; Hossack et al., 1985; Nickelsen et al., 1985). The Valdres Group can be subdivided into three lithostratigraphical parts and informally named (in ascending order) according to the characteristic localities; Rabalsmellen-type, Rognslifjell-type and Rundemellen-type sandstones (Fig. 2) (Loeschke, 1967; Loeschke \& Nickelsen, 1968). The Valdres Group contains three well-defined conglomerate units, in addition to the arkosic sandstones. The uppermost conglomerate unit, the tillite, marks the boundary between the Valdres and Mellsenn groups (Loeschke \& Nickelsen, 1968), while the conglomerates in the lower parts of the Valdres Group are dominated by braided stream/ braid bar configurations.
The sedimentary succession of the Valdres Group at Grønsennknippa and Mellane (Rundemellen and Skarvemellen) is generally of low metamorphic grade, commonly lower greenschist facies (Loesche \& Nickelsen, 1968; Heim et al., 1977; Bockelie \& Nystuen, 1985; Kumpulainen \& Nystuen, 1985), while the Ormtjernkampen succession (about $30 \mathrm{~km}$ east of Mellane, Fig. 1) belongs to the upper greenschist facies.

\section{Tectonic development}

The formation of the Baltoscandian rift basins has been related to the continental break-up of Rodinia, separating the Laurentian craton to the northwest from the Baltoscandian craton to the southeast (Lamminen et al., 2015). Kumpulainen \& Nystuen (1985) suggested establishment of the Hedmark, Valdres and Risbäck rift basins at the crest of a 500-1000 km-wide, thermally elevated, crustal dome. This rift system probably had a NW-SE to NNE-SSW trend. It comprised grabens, crustal depressions and basement highs. Coarse-clastic, continental, pre-Varangerian ice-age sedimentation dominated during the rift basin development.

The Neoproterozoic successions of southwestern Norway were folded and thrusted on top of each other during the Caledonian Orogeny, characterised by WNW-ESE thrust-nappe translation. The major nappe complexes have traditionally been grouped into Lower, Middle, Upper and Uppermost allochthons (Roberts \& Gee, 


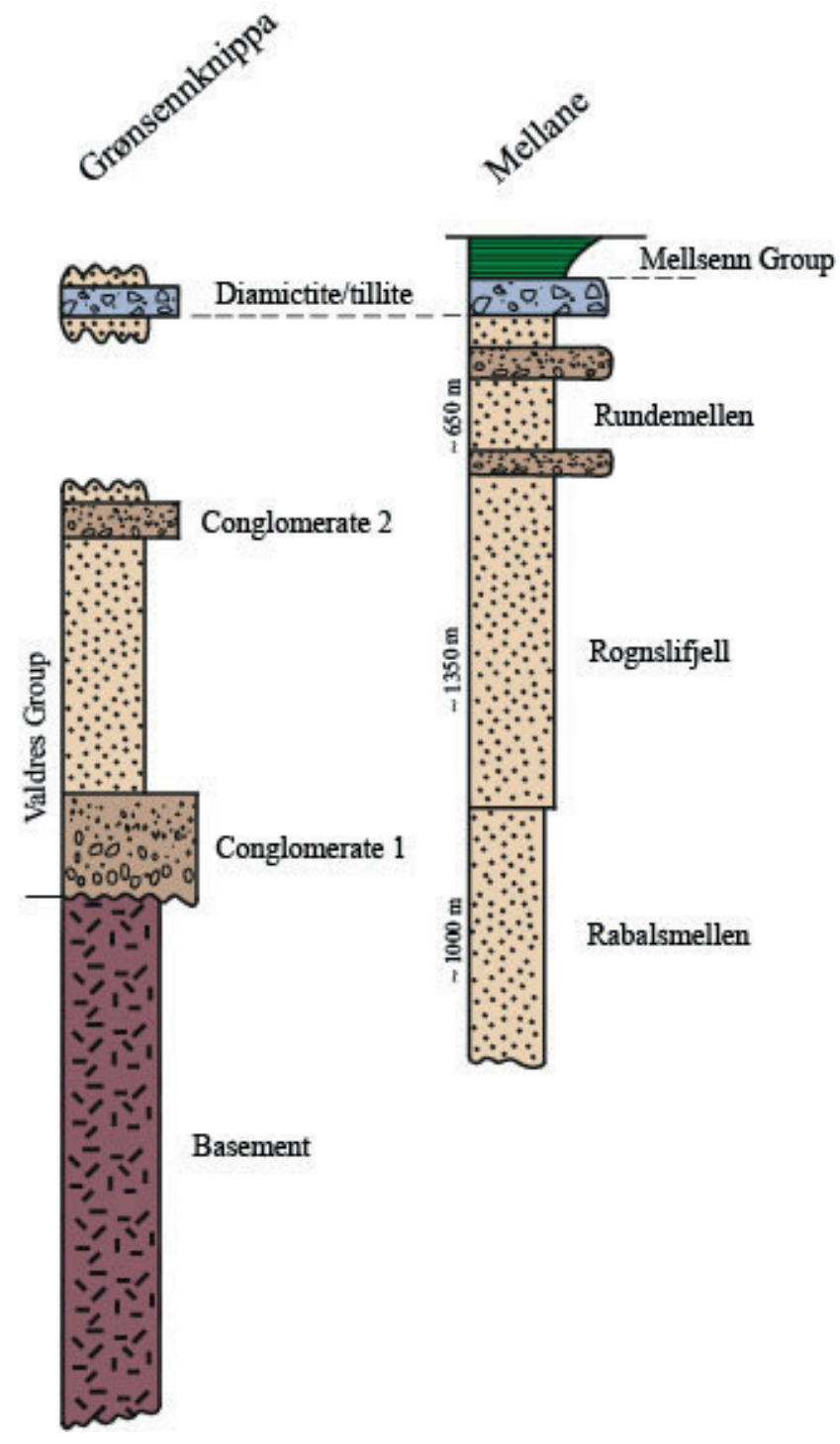

Figure 2. Simplified lithostratigraphic columns of Grønsennknippa and Mellane, modified from Nickelsen et al. (1985). A correlation is suggested between the diamictite at Grønsennknippa and the tillite in the Mellane section.

1985; Lamminen et al., 2015; Bjørlykke \& Olesen, 2018), with proposed lateral displacements of up to 300-400 km (Rice, 2005; Gee et al., 2010). Thrust sheets within the nappes are composed of different varieties of late Proterozoic to Silurian metasedimentary and igneous rocks (Roberts \& Gee, 1985).

\section{Valdres Group vs. Hedmark Group}

Glacial deposits of late Neoproterozoic age have been recorded on most continents, even at low latitudes, implying that the Earth was affected by a global glaciation (Bingen et al., 2005). These Neoproterozoic glacial deposits appear as tillites/diamictites in the Hedmark and Valdres basins (Nystuen \& Lamminen,
2011; Småkasin, 2017; Sørhus, 2017; Nordeng, 2018; Stokkebekk, 2018). The tillite of the Hedmark Group (Moelv Tillite) carries a siltstone and sandstone matrix,, with a mineralogical composition comparable to the overlying Ekre and Vangsås formations (Nystuen \& Lamminen, 2011).

The tillite/diamictite in the Valdres Basin is composed of lithologies comparable to the Moelv Tillite in the Hedmark Basin (Nystuen \& Lamminen, 2011; Småkasin, 2017; Sørhus, 2017; Nordeng, 2018; Stokkebekk, 2018). The tillites are capping successions dominated by coarse-clastic alluvial fans and thick clastic fluvial sequences. In the Ormtjernkampen area, the tillite was deposited on top of an alluvial-fan succession and on crystalline basement, whereas in the Mellane and possibly Grønsennknippa areas, it was deposited on top of thick fluvial successions (Nystuen \& Lamminen, 2011; Småkasin, 2017; Sørhus, 2017; Nordeng, 2018; Stokkebekk, 2018).

\section{Methods}

In this study, three sites of the Valdres Group are in focus; Mellane (including both the Skarvemellen and the Rundemellen sections), Grønsennknippa and Ormtjernkampen (Fig. 3). Fieldwork and sampling were performed at the three sites in 2016, 2017 and 2018, respectively. In total, more than 300 samples have been collected for mineralogical, petrographical and palynological analysis (Småkasin, 2017; Sørhus, 2017; Nordeng, 2018; Stokkebekk, 2018).

Palynological processing was conducted according to standard techniques (Traverse, 2007). Firstly, contamination (moss, vegetation, etc.) on the surfaces of the whole-rock samples was removed with soap and steel brush, before the sample was air-dried at $50^{\circ} \mathrm{C}$. All samples were then crushed to small fragments with hammer and anvil, and the equipment was carefully washed and dried with ethanol between preparing each sample. About $20 \mathrm{~g}$ of the crushed samples was then placed in propylene containers with a lycopodium tablet, and dry weight was determined. Subsequently, all samples were treated first with $38 \%$ hydrochloric acid $(\mathrm{HCl})$ and then with $40 \%$ hydrofluoric acid (HF) in order to dissolve the carbonate and silicate minerals. The samples were stored in warm water at $60^{\circ} \mathrm{C}$ for 2 days to enhance the silica dissolution by HF. The residue was treated with hydrochloric acid $(\mathrm{HCl})$ in order to dissolve the fluorine-silica gel. The liquid was separated from the resulting residue by repeated decantation. Finally, the residue was washed until neutral $\mathrm{pH}$ was obtained.

Organic matter and palynomorphs were extracted from the HF- and $\mathrm{HCl}$-treated rock samples with a 250 

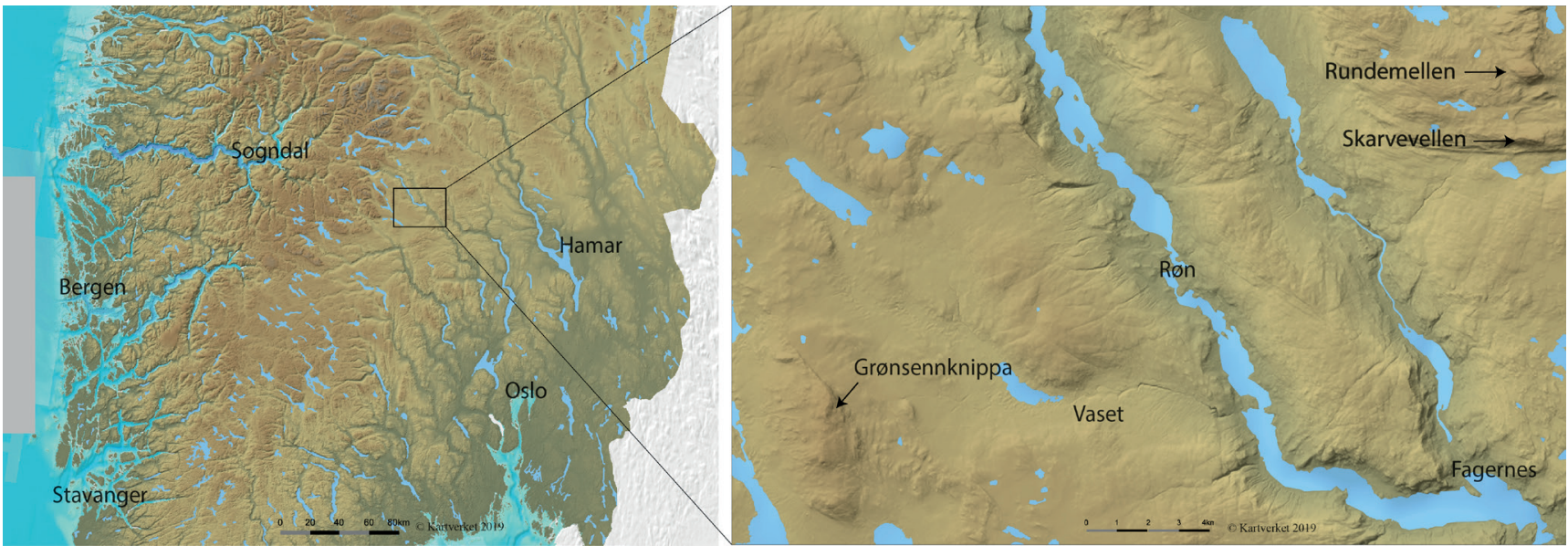

Figure 3. Map of the study area in Valdres, Oppland county. The Valdres Group succession is exposed at the Grønsennknippa study site in Vestre Slidre, and at Skarvemellen and Rundemellen from the Mellane area in Øystre Slidre (www.norgeskart.no).

$\mu \mathrm{m}$ mesh sieve and with a $7 \mu \mathrm{m}$ nylon mesh sieve. The residue was decanted and mixed with zinc chloride $\left(\mathrm{ZnCl}_{2}\right.$ with density $\left.2.91 \mathrm{~g} / \mathrm{cm}^{3}\right)$ in a test tube for heavyliquid separation of the organic matter from minerals that did not dissolve in the HF treatment. After 24 hours, the light organic particles floated in the heavy liquid, while the denser minerals had sunk to the bottom of the test tube. Next, samples were once more sieved with the $7 \mu \mathrm{m}$ nylon mesh. The organic residues were mounted in Entallan for light microscopic study. The organic particles were measured and photographed using a Leitz Diaplan Type 307 microscope with a Zeiss AxioCam ERc 5 microscope camera.

\section{Results}

\section{Palynology}

Twenty-one samples from the Valdres Group were processed and analysed for palynology: 3 from Rundemellen, 3 from Skarvemellen, 5 from Grønsennknippa and 10 from Ormtjernkampen. The organic residue was screened for acritarchs. The processed samples from the Mellane area were extracted from fine-grained, parallel-laminated and structureless sandstones, in addition to a poorly sorted tillite sample. The samples from Grønsennknippa were extracted from interbedded fine-grained layers within partly clastsupported conglomerate units. Additionally, one sample representing a proposed diamictite was processed. The samples from Ormtjernkampen were extracted from conglomerate, sandstone and diamictite beds.

When analysing palynologically-poor Proterozoic samples, it is important to evaluate the possibility of contamination. The exposed bedrock at the three sites was locally well overgrown by thick layers of recent mosses and lichens. Although samples were carefully cleaned in the lab prior to processing, contamination cannot be $100 \%$ excluded. The recovered, observed, possible organic matter and the acanthomorph acritarch were not observed in petrographical thin-sections but extracted from sieved, dissolved hard-rock samples as described in the methods section.

\section{Acantomorphic acritarch}

One acantomorphic acritarch was extracted from an interlayered fine-grained sandstone bed within a section dominated by coarse-grained sandstones with interbedded conglomerate layers (sample RUND 2-316). The current sample was taken from the Rundemellen section at Mellane within the Rundemellen unit type sandstone, c. 185-190 m stratigraphically below the Mellsenn Group, and the tillite on the top of the Valdres Group (Sørhus, 2017).

The recovered specimen is a sub-spheroidal dark vesicle (Fig. 4). The vesicle is c. $90 \mu \mathrm{m}$ in diameter along the longest axis, and c. $70 \mu \mathrm{m}$ along the shortest axis. Eight distinct processes project from the exterior surface of the vesicle, ranging from 8 to $20 \mu \mathrm{m}$. The processes are c. $5 \mu \mathrm{m}$ in width at the periphragm/exterior surface, thinning towards the top tip to $\mathrm{c} . \leq 1 \mu \mathrm{m}$. The processes have two forms, simple single spines and single spines with a T-shaped flat top and c. $8 \mu \mathrm{m}$ in length. The whole spiny acritarch is opaque black, which indicates a TAI (thermal alteration index after Batten, 1981, 1982) of 7 , representing thermal alteration at $>>200^{\circ} \mathrm{C}$. The TAI colour of this acritarch matches the greenschist metamorphism grade indicated by the petrography.

Most of the palynological preparations from other locations contained several types of organic-walled 


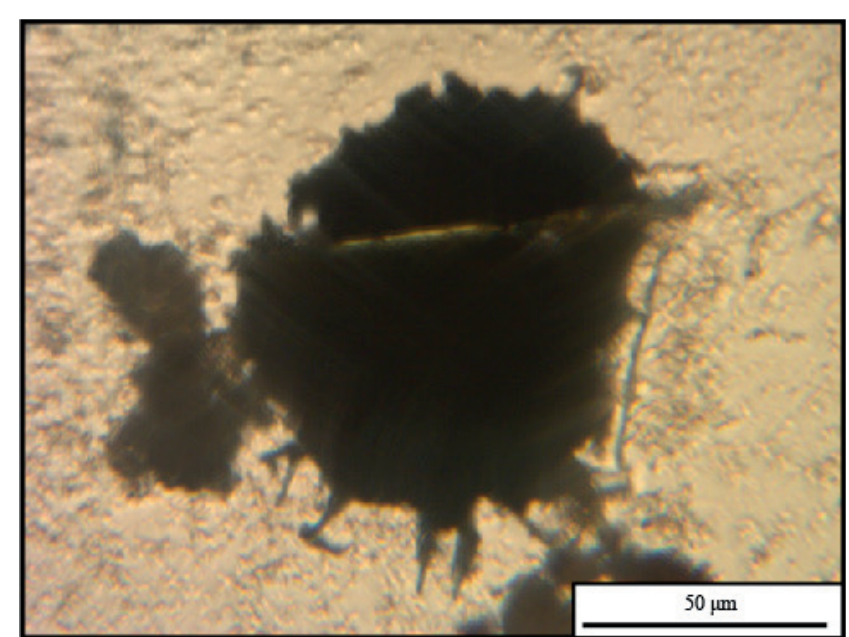

Figure 4. Photomicrograph of the acantomorph acritarch (Trachyhystrichosphaera?) recovered from the Valdres Group at the Rundemellen section at Mellane (Sample RUND-2-3-16 (3)). The sample will be stored at NHM, UiO.

remains (Fig. 5), which could be assigned to colonial structures of sphaeromorph or herkomorph acritarchs. However, their colour, being light-medium brown to dark brown indicates a TAI of 3-5, which differs significantly from the acanthomorphic acritarch. As the thermal alteration of these organic structures does not match the degree of metamorphism as indicated by petrography, these acritarch-like structures are most likely remains of lichens and fungi contamination from modern lichen colonies growing on the rock surface as encrustation.

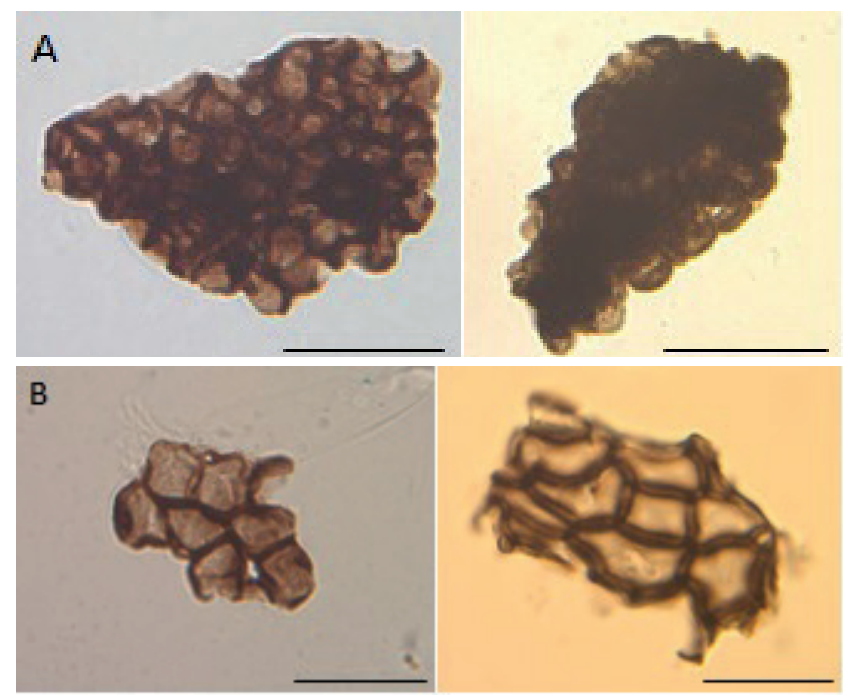

Figure 5. Organic debris representing tissue fragments of lichens (modern contamination) that have some resemblance with (A) colonial sphaeromorphic or (B) herkomorphic acritarchs, but the colour of the tissue is too bright for the maturity that is indicated by petrographic analysis. (A) from sample GRØ-4a-57-17 (1) (left) and RUND-1-5-16 (1) (right). (B) from sample GRØ-2a-6-17 (3) (left) and RUND-1-11-16 (1) (right). The scale bars are $20 \mu \mathrm{m}$.

\section{Discussion}

\section{Lithostratigraphy}

The lithostratigraphy of the Valdres Group is similar at Grønsennknippa, Mellane (Skarvemellen and Rundemellen) and Ormtjernkampen, with conglomerates and sandstones and interbedded thin layers of finegrained sandstones and shales. The Grønsennknippa and Ormtjernkampen sections are dominated by conglomerate units (Nickelsen, 1974; Corfu \& Heim 2014; Nordeng, 2018; Stokkebekk, 2018), while the Skarvemellen and Rundemellen sections are richer in sandstone formations (Småkasin, 2017; Sørhus, 2017). The Grønsennknippa site and the Rundemellen and Skarvemellen (Mellane) sites are presently located c. $25 \mathrm{~km}$ from each other, while Ormtjernkampen is about $30 \mathrm{~km}$ farther to the east (Figs. $1 \& 3$ ). The two Mellane sites are only c. $2 \mathrm{~km}$ apart. They have both been interpreted to represent braided stream/alluvial environments (Småkasin, 2017; Sørhus, 2017), while the Grønsennknippa succession is most likely associated with a more proximal setting (Nordeng, 2018; Stokkebekk, 2018). The sedimentary provenance area is suggested to be the same for Skarvemellen and Rundemellen, in which only minor variations are noted in the sandstone mineralogy (Småkasin, 2017; Sørhus, 2017).

Thin layers of diamictite/tillite are described at Skarvemellen (Småkasin, 2017), Rundemellen (Sørhus, 2017) and Grønsennknippa (Nordeng, 2018; Stokkebekk, 2018). A similar lithostratigraphic marker layer is also present at Ormtjernkampen (Nickelsen, 1974; Nystuen \& Lamminen, 2011). The Valdres Group tillite/diamictite occurs both as marginal and more distal deposits and probably has a wide regional extent within the Valdres Basin, comparable to the Moelv Formation in the Hedmark Basin (Siedlecka et al., 2004; Småkasin, 2017; Sørhus, 2017; Nordeng, 2018; Stokkebekk, 2018). According to Nystuen (1987) the tillite was deposited during the Varangerian glaciation and represents an important correlative unit within the Valdres Basin as well as to the Hedmark Group of the Hedmark Basin.

\section{Petrography}

The arkosic sediments from Grønsennknippa and Mellane revealed relatively homogeneous compositions, dominated by quartz and feldspars. The main difference in the mineralogical content of Grønsennknippa and Mellane (Skarvemellen and Rundemellen) is the higher content of quartz at Mellane and higher content of plagioclase at Grønsennknippa (Småkasin, 2017; Sørhus, 2017; Nordeng, 2018; Stokkebekk, 2018). This suggests a more proximal origin for the Grønsennknippa section compared to the Skarvemellen and Rundemellen sections (or a different provenance), which is supported 
by the dominance of coarse-grained pebble material and associated angular, medium- to coarse-grained sand matrix in the Grønsennknippa section. The fairly mature sediments of Mellane were probably deposited in a more central position in the basin (Nordeng, 2018; Stokkebekk, 2018).

\section{Metamorphism}

The metamorphic index minerals (Turner \& Verhoogen, 1960; Philpotts \& Ague, 2009) identified in the Valdres Group are epidote, titanite, muscovite, biotite, garnet and chlorite, indicating greenschist facies (Nordeng, 2018; Stokkebekk, 2018). In the samples from Ormtjernkampen a somewhat higher degree of recrystallisation is apparent, carrying chlorite, actinolite and epidote, possibly approaching upper greenschist facies (Nickelsen, 1974). Local metamorphic variations are indicated in the study area, as the index mineral assemblage varies. Sericite dominates the intergranular matrix and encloses the grains. Staurolite, kyanite or sillimanite were not observed (Stokkebekk, 2018), consequently amphibolite-facies metamorphism is not indicated (Philpotts \& Ague, 2009).

The metamorphic grade can be related to tectonic phases within the Silurian to Early Devonian Scandian collisional orogeny (Gee et al., 2008). The greenschist index minerals and the clastic minerals have been overprinted by sericitisation likely associated with the subsequent retrograde metamorphism (Nordeng, 2018; Stokkebekk, 2018). The abundant sericite may be an alteration product from K-feldspar and plagioclase (Barker, 1998).

\section{Palynology}

In the following section we briefly present the morphology and the first discovery of organic-walled microfossils in the Valdres Group, hopefully triggering further investigations of the fossil assemblages in one of the least understood sedimentary formations in the southern Scandinavian Caledonides. Previously, there have been studies of acritarchs from southern Norwegian metasedimentary rocks (Vidal \& Nystuen, 1990a) but with focus on the early Palaeozoic. The same authors studied the organic-walled microfossils from the Neoproterozoic Hedmark Group in the Lake Mjøsa type area in southern Norway (Vidal \& Nystuen, 1990b). They reported for the first time abundant and relatively well preserved acritarch assemblages from fine-grained shales within the Brøttum, Biskopåsen and Biri formations. Dictyonema graptolites (Nickelsen et al., 1985), orthoid brachiopods (Loeschke, 1967) and Early and Middle Ordovician age graptolites corresponding to those from the Oslo region (Bjørlykke, 1905) have been recognised from the upper part of the Cambrian Mellsenn Group of the Valdres Basin (Nickelsen et al., 1985), which is stratigraphically above the Valdres Group. Organicwalled microfossils, however, have not previously been recovered from the Valdres Group.

\section{Acantomorphic acritarchs}

One specimen of a poorly preserved acantomorphic acritarch was encountered in the samples (Fig. 4). Despite the poor preservation, the visible morphological features show a resemblance to the acritarch genus Trachyhystrichosphaera described by Knoll (1984, 1992), Butterfield et al. (1994) and Riedman et al. (2014) on Svalbard and from other late Proterozoic acritarch assemblages. The acantomorph specimen from the Valdres Group is, however, only c. $90 \mu \mathrm{m}$ in diameter, whereas the specimens of Trachyhystrichosphaera described from Svalbard range from 95 to $235 \mu \mathrm{m}$ in diameter. The Valdres specimen lacks the outer envelope of the vesicle and therefore resembles the vesicle size of the genus Trachyhystrichosphaera. Randomly projected c. 10-15 $\mu \mathrm{m}$ processes are recognised. Some of the processes, at the upper-right quarter of the vesicle in the studied specimen, show protrusion through a relatively proximal sheath.

The genus Trachyhystrichosphaera was suggested as a biostratigraphic index fossil for the late Riphean of the Neoproterozoic (Kaufmann, 1992; Vidal et al., 1993; Butterfield et al., 1994). Newer studies have indicated a longer range from the late Mesoproterozoic (Tang et al., 2015; Baludikay et al., 2016; Loron et al., 2019). A recent compilation by Riedman \& Sadler (2018) from radiometrically dated late Proterozoic sedimentary rocks shows that the Last Appearance Date (LAD) of Trachyhystrichosphaera has been constrained to $738 \mathrm{Ma}$. If the identification of the spinous acritarch found in the present study can be confirmed by additional findings as Trachyhystrichosphaera, its presence would support the stratigraphic correlation of the Valdres Group to the late Riphean, not younger than the Cryogenian. It cannot be excluded that the acritarch finding is recovered from reworked lithoclasts which are stratigraphically older, e.g., Tonian in age (Loron, 2016).

The first findings of acritarchs in Neoproterozoic sedimentary rocks from Finnmark (northern Norway) were reported by Timofeev (1963). Following Timofeev's pioneering work Manum (1967) reported for the first time the occurrence of several acritarch morphotypes from the Neoproterozoic sedimentary rocks of the Hedmark Group in southeastern Norway. More recent palynological studies in this area by Vidal (1990) and Vidal \& Nystuen (1990b) found diverse and partly well preserved acritarch assemblages with colonial sphaeromorphic, smooth solitary sphaeromorphic and polygonomorphic acritarchs, and one type of an acantomorphic acritarch. Downie (1982) described younger, Early Cambrian, acritarch assemblages from the Lake Mjøsa area, SE Norway. Yet, none of those forms 
described in these earlier studies (Manum, 1967; Vidal \& Nystuen, 1990b) have been found in the analysed samples of the Valdres Group. However, some of the acritarchs reported by Vidal \& Nystuen (1990b) showed a significantly lower thermal alteration grade, TAI 3-4, than those of the present study (TAI 7). This indicates differences in local degrees of metamorphism between the Hedmark and the Valdres Group. The black colour (TAI 7) of the Valdres Group specimen is similar to the black colour of Cambrian conodonts from overlying strata. Conodonts from the upper part of the CambroOrdovician Ørnberget Formation of the Synnfjell thrust sheet (Fig. 1) had a CAI (colour alteration index) of 5-5.5 (Nickelsen et al., 1985). Assuming a geothermal gradient of $30^{\circ} \mathrm{C} / \mathrm{km}$, an attained temperature of 300 to $400^{\circ} \mathrm{C}$ would correspond to $>10-13 \mathrm{~km}$ of overburden thickness (Nickelsen et al., 1985).

The marked difference in acritarch assemblages from the Hedmark Group in comparison to the species found in the Valdres Group may reflect different causes including differences in sedimentary or tectonic settings. It could also be the result of insufficient sampling strategy and the use of standard palynological processing methods instead of a special treatment technique developed for extraction of delicate Proterozoic microfossils (e.g., Butterfield et al., 1994). Therefore, it is too early to draw any wide conclusions on the significance of the preliminary finding of one acritarch from the Valdres Group.

\section{Conclusions}

The Neoproterozoic Valdres Group generally reflects high-energy deposits laid down by stream flows/sheet flows in braided-river systems in alluvial/fluvial settings, possibly associated with (wet) alluvial fan(s).

The Grønsennknippa, Mellane (Skarvemellen, Rundemellen) and Ormtjernkampen sites can be lithostratigraphically correlated, not least due to the diamictite/ tillite beds present. A more mature composition (enriched in quartz) for the Rundemellen-type sandstone at Mellane is indicated by petrographical data, in comparison with the feldspar-rich Grønsennknippa sections. The Mellane successions were probably deposited in a more central-basin position compared to the Grønsennknippa section. A detailed sedimentological analysis of the Ormtjernkampen area is yet to be undertaken.

In the Rundemellen section, one specimen of a poorly preserved acantomorphic acritarch, Trachyhystrichosphaera, was found within the Rundemellen unit, while the other analysed shales in Grønsennknippa, Skarvemellen and Ormtjernkampen were barren of organic remnants that can be assigned to acritarchs.
Acknowledgements. The Department of Geosciences at University of Oslo kindly supported the project for three years through the so-called 'Småforskprogrammet' and 4 master candidates finalised their theses (Nordeng, Småkasin, Stokkebekk, Sørhus). Roy Gabrielsen is thanked for field participation and discussions of the Grønsennknippa sections, and Mufaz Naoroz, Thanusha Naidoo and Salahalldin Akhavan are thanked for aiding the lab preparations. We highly appreciated discussions with Johan Petter Nystuen on both general and detailed stratigraphical and sedimentological issues and Håkon Austerheim for valuable discussions related to petrography and metamorphism. Adrian Read kindly did proof reading and corrected the English in an earlier version. The comments and suggestions of referees Morten Smelror and Øyvind Hammer, and editor Trond Slagstad, are highly appreciated.

\section{References}

Baludikay, B.K., Storme, J.-Y., Francois, C., Baudet, D. \& Javaux, E.J, 2016: A diverse and exquisitely preserved organic-walled microfossil assemblage from the Meso-Neoproterozoic MbujiMayi Supergroup (Democratic Republic of Congo) and implications for Proterozoic ostratigraphy. Precambrian Research 281, 166-184. https://doi.org/10.1016/j.precamres.2016.05.017.

Barker, A.J. 1998: Introduction to metamorphic textures and microstructures, $2^{\text {nd }}$ ed. Cheltenham, U.K., Stanley Thornes Ltd, 264 pp. https://doi.org/10.1007/978-1-4615-7291-6.

Batten, D.J. 1981: Palynofacies, organic maturation and source potential for petroleum. In Brooks, J. (ed.): Organic maturation studies and fossil fuel exploration, Academic Press, London, pp. 201-223.

Batten, D.J. 1982: Palynofacies, palaeoenvironments and petroleum. Journal of Micropalaeontology 1, 107-114. https://doi.org/10.1144/jm.1.1.107.

Bingen, B., Griffin, W.L., Torsvik, T.H. \& Seaeed, A. 2005: Timing of Late Neoproterozoic glaciation on Baltica constrained by detrital zircon geochronology in the Hedmark Group, south-east Norway. Terra Nova 17, 250-258. https://doi.org/10.1111/j.1365-3121.2005.00609.x.

Bjørlykke, K.O. 1905: Det centrale Norges fjeldbygning. Norges Geologiske Undersøkelse 39, 1-595.

Bjørlykke, A. \& Olesen, O. 2018: Caledonian deformation of the Precambrian basement in southeastern Norway. Norwegian Journal of Geology, 98, 1-16. https://doi.org/10.17850/njg98-4-05.

Bockelie, J.F. \& Nystuen, J.P. 1985: The southeastern part of the Scandinavian Caledonides. In Gee, D.G. \& Sturt, B.A. (eds.): The Caledonide Orogen- Scandinavia and Related Areas, John Wiley \& Sons Ltd, Chichester, pp. 69-88.

Butterfield, N.J., Knoll, A.H. \& Swett, K. 1994: Paleobiology of the Neoproterozoic Svanbergfjellet Formation, Spitsbergen. Lethaia 27, 76-76.

Corfu, F. \& Heim, M. 2014: Geology and U-Pb geochronology of the Espedalen Complex, southern Norway, and its position in the Caledonian nappe systems. Geological Society of London, Special Publications 390, 223-239.

Downie, C. 1982: Lower Cambrian acritarchs from Scotland, Norway, Greenland and Canada. Transactions of the Royal Society of Edinburgh: Earth Sciences 72, 257-285. https://doi.org/10.1017/S0263593300010051.

Gee, D.G., Fossen, H., Henriksen, N. \& Higgins, A.K. 2008: From the early Paleozoic platforms of Baltica and Laurentia to the Caledonide Orogen of Scandinavia and Greenland. Episodes 31, 44-51.

Gee, D.G., Juhlin, C., Pascal, C. \& Robinson, P. 2010: Collisional Orogeny in the Scandinavian Caledonides (COSC). Journal of the Geological Society of Sweden 132, 29-44. https://doi.org/10.1080/11035891003759188. 
Heim, M., Schärer, U. \& Milnes, A.G. 1977: The nappe complex in the Tyin-Bygdin-Vang region, central southern Norway. Norwegian Journal of Geology 57, 171-178.

Hossack, J.R. 1968: Pebble deformation and thrusting in the Bygdin area (Southern Norway). Tectonophysics 5, 315-339. https://doi.org/10.1016/0040-1951(68)90035-8.

Hossack, J.R., Garton, M.R. \& Nickelsen, R.P. 1985: The geological section from the foreland up to the Jotun thrust sheet in the Valdres area, south Norway. In Gee, D.G. \& Sturt, B. A. (eds.): The Caledonide Orogen-Scandinavia and Related Areas, John Wiley \& Sons Ltd, Chichester, pp. 443-446.

Kaufman, A.J., Knoll, A.H. \& Awramik, S.M. 1992: Biostratigraphic and chemostratigraphic correlation of Neoproterozoic sedimentary succession: Upper Tindir Group, northwestern Canada, as a test case. Geology 20, 181-185. https://doi.org/10.1130/0091-7613(1992)020<0181:BACCON>2.3.CO;2.

Knoll, A.H. 1984: Microbiotas of the Late Precambrian Hunnberg Formation, Nordaustlandet, Svalbard. Journal of Paleontology 58, 131-162.

Knoll, A.H. 1992: Vendian microfossils in metasedimentary cherts of the Scotia Group, Prins Karls Forland, Svalbard. Palaeontology 35, 751-774.

Kumpulainen, R. \& Nystuen, J.P. 1985: Late Proterozoic basin evolution and sedimentation in the westernmost part of Baltoscandia. In Gee, D.G. \& Sturt, B.A. (eds.): The Caledonide Orogen- Scandinavia and Related Areas, John Wiley \& Sons Ltd, Chichester, pp. 213-232.

Lamminen, J., Andersen, T. \& Nystuen, J.P. 2015: Provenance and rift basin architecture of the Neoproterozoic Hedmark Basin, South Norway inferred from $\mathrm{U}-\mathrm{Pb}$ ages and Lu-Hf isotopes of conglomerate clasts and detrital zircons. Geological Magazine 152, 80-105. https://doi.org/10.1017/S0016756814000144.

Loeschke, J. 1967: Zur Stratigraphie und Petrographie des ValdresSparagmites und der Mellsenn-Gruppe bei Mellane/Valdres (SüdNorwegen). Geological Survey of Norway 243, 5-66.

Loeschke, J. \& Nickelsen, R.P. 1968: On the age and tectonic position of the Valdres Sparagmite in Slidre (Southern Norway). Neues Jahrbuch für Geologie und Paläontologie 131, 337-367.

Loron, C.C. 2016: The Biodiversity of Organic-Walled Eukaryotic Microfossils from the Tonian Visingsö Group, Sweden. MSc thesis, Department of Earth Sciences, Uppsala University, 103 pp.

Loron, C.C., Rainbird, R.H., Turner, E.C., Greenman, J.W. \& Javaux, E.J. 2019: Organic-walled microfossils from the late Mesoproterozoic to early Neoproterozoic lower Shaler Supergroup (Arctic Canada): Diversity and biostratigraphic significance. Precambrian Research 321, 349-374. https://doi.org/10.1016/j.precamres.2018.12.024.

Manum, S. 1967: Microfossils from Late Precambrian sediments around lake Mjøsa, Southern Norway. Geological Survey of Norway 251, 45-52.

Nickelsen, R.P., 1974: Geology of the Røssjøkollan-Dokkvath Area, Oppland. Geological Survey of Norway 314, 53-160.

Nickelsen, R.P., Hossack, J.R. \& Garton, M.R. 1985: Late Precambrian to Ordovician stratigraphy and correlation in the Valdres and Synnfjell thrust sheets of the Valdres area, southern Norwegian Caledonides; with some comments on sedimentation. In Gee, D.G. \& Sturt, B.A. (eds.): The Caledonide Orogen-Scandinavia and Related Areas, John Wiley \& Sons Ltd, Chichester, pp. 369-378.

Nordeng, E.N. 2018: The Neoproterozoic Valdres Group at Grønsennknippa, Vestre Slidre Field observations and laboratoryanalyses. Unpublished MSc thesis, University of Oslo, $182 \mathrm{pp}$.

Nystuen, J.P. 1982: Late Proterozoic basin evolution on the Baltoscandian craton: the Hedmark Group, southern Norway. Geological Survey of Norway 375, 1-74.

Nystuen, J.P. 1987: Synthesis of the tectonic and sedimentological evolution of the late Proterozoic-early Cambrian Hedmark Basin, the Caledonian Thrust Belt, southern Norway. Norwegian Journal of Geology 67, 395-418.
Nystuen, J.P. \& Lamminen, J. 2011: Neoproterozoic glaciation of South Norway: from continental interior to rift and pericratonic basins in western Baltica. Geological society of London 36, 613-622. https://doi.org/10.1144/M36.59.

Nystuen, J.P. \& Sæther, T. 1979: Clast studies in the Late Precambrian Moelv Tillite and Osdal Conglomerate, Sparagmite Region, south Norway. Norwegian Journal of Geology 59, 239-251.

Nystuen, J.P., Andresen, T., Kumpulainen, R. \& Siedlecka, A. 2008: Neoproterozoic basin evolution in Fennoscandia, East Greenland and Svalbard. Episodes 31, 35-43. https://doi.org/10.18814/epiiugs/2008/v31i1/006.

Philpotts, A. \& Ague, J. 2009: Principles of igneous and metamorphic petrology, $2^{\text {nd }} \mathrm{ed}$. Cambridge University Press, $667 \mathrm{pp}$. https://doi.org/10.1017/CBO9780511813429.

Rice, A.H.N. 2005: Quantifying the exhumation of UHP-rocks in the Western Gneiss Region, SW Norway: A branch-line-balanced cross-section model. Austrian Journal of Earth Sciences 98, 2-21.

Riedman, L.A. \& Sadler, P.M. 2018: Global species richness record and biostratigraphic potential of early to middle Neoproterozoic eukaryote fossils. Precambrian Research 319, 6-18.

Riedman, L.A., Porter, S.M., Halverson, G.P., Hurtgen, M.T. \& Junium, C.K. 2014: Organic-walled microfossil assemblages from glacial and interglacial Neoproterozoic units of Australia and Svalbard. Geology 42, 1011-1014. https://doi.org/10.1130/G35901.1.

Roberts, D. \& Gee, D.G. 1985: An introduction to the structure of the Scandinavian Caledonides. In Gee, D. \& Sturt, B. (eds.): The Caledonide orogen-Scandinavia and related areas, John Wiley \& Sons Ltd., pp. 55-68.

Siedlecka, A., Roberts, D., Nystuen, J.P. \& Olovyanishnikov, V.G. 2004: Northeastern and northwestern margins of Baltica in Neoproterozoic time: evidence from the Timanian and Caledonian Orogens. Geological Society of London 30, 169-190. https://doi.org/10.1144/GSL.MEM.2004.030.01.15.

Småkasin, R.Ø. 2017: The Eocambrian Valdres Group at Skarvemellen, Mellane - Field observations and sedimentpetrographical analysis. Unpublished MSc thesis, University of Oslo, $101 \mathrm{pp}$.

Stokkebekk, E. 2018: The Valdres Group at Grønsennknippa, Vestre Slidre. Field observations and sediment-petrographical analysis. Unpublished MSc thesis, University of Oslo, 219 pp.

Sørhus, K. 2017: The Eocambrian Valdres Group at Rundemellen, Mellane - Field observations and sedimentpetrographical analysis. Unpublished MSc thesis, University of Oslo, 73 pp.

Tang, Q., Pang, K., Yuan, X., Wan, B. \& Xiao, S. 2015: Organic-walled microfossils from the Tonian Gouhou Formation, Huaibei region, North China Craton, and their biostratigraphic implications. Precambrian Research 266, 296-318.

https://doi.org/10.1016/j.precamres.2015.05.025.

Timofeev, B.V. 1963: On organic remains in the Eocambrian of Norway. Norwegian Journal of Geology 43, 473-476.

Traverse, A. 2007: Palaeopalynology, $2^{\text {nd }}$ edition. In Landman, N.H. \& Jones, D.S. (eds.): Topics In Geobiology, Vol. 28, Springer Dordrecht, The Netherlands, pp. 1-813.

Turner, F.J. \& Verhoogen, J. 1960: Igneous and metamorphic petrology. McGraw-Hill Book Company Inc., 694 pp.

Vidal, G. 1990: Giant acanthomorph acritarchs from the Upper Proterozoic in Southern Norway. Palaentology 33, 287-298.

Vidal, G. \& Nystuen, J.P. 1990a: Lower Cambrian acritarchs and the Proterozoic- Cambrian boundary in southern Norway. Norwegian Journal of Geology 70, 191-222.

Vidal, G. \& Nystuen, J.P. 1990b: Micropaleontology, depositional environment, and biostratigraphy of the Upper Proterozoic Hedmark Group, Southern Norway. American Journal of Science 290A, 170-211.

Vidal, G., Moczydłowska, M. \& Rudavskaya, V.A. 1993: Biostratigraphic implications of a Chuaria-Tawuia assemblage and associated acritarchs from the Neoproterozoic of Yakutia. Palaeontology 36, 387-402. 